\title{
The Dissolution Of Muslim Marriage Act, 1939 May Provide More Rights To Women Of Subcontinent If Applied According To True Doctrine Of Maliki School Of Islamic Jurisprudence: An Overview
}

\author{
Yasir Arafat \\ International Islamic University Islamabad
}

\begin{abstract}
Dissolution of Muslim Marriage Act, 1939 (DMMA) is sole document in the history of Sub continent, which is a departure from the Hānāfi School of Islamic thought. It is based on the Maliki School of Islamic jurisprudence. The two main purposes of this document were to grant women more right which were not there in the Hānāfi School of Islamic jurisprudence and to stop women from committing apostasy to get out of their marriage. However, when the DMMA is critically evaluated it is found that, DMMA may provide more right to women of subcontinent if applied according to real intention of Maliki school of islamic jurisprudence. In this paper an evaluation of the DMMA, 1939 is made just to clarify that there were more women rights hidden there but this law was not implimented in its real sense and also the basic purpose seems to be stop women from committing apostasy instead of giving more rights regarding dissolution of marriage.

$$
\begin{aligned}
& \text { ثنإن }
\end{aligned}
$$

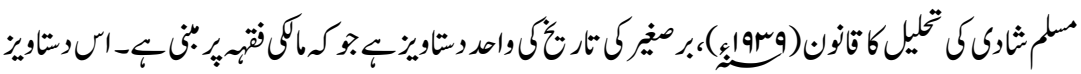

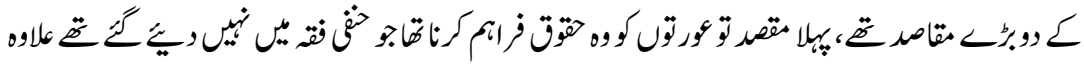

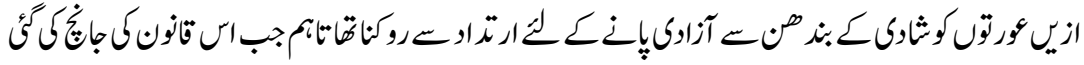

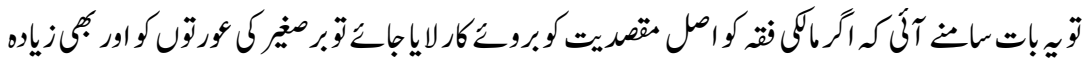

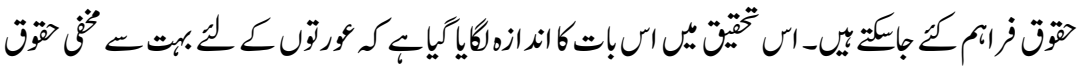

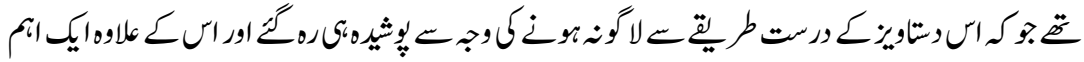

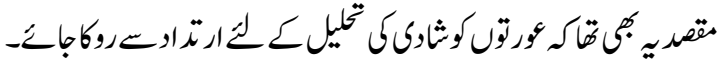




\section{History of DMMA, 1939}

In 1913, a Muslim husband applied to a colonial court in India for the restitution of conjugal rights, but his in-laws refused to let his wife join him. His in-laws claimed that the woman had become an apostate and thus, according to Islāmic law interpreted by the Hānäfi, was no longer the claimant's wife. The judge asked the claimant to obtain a fatwā,(legal suggestion from certified Islāmic scholar) to clarify the position of Islāmic law on the status of his marriage. The claimant, therefore, approached Maulana Ashraf Ali Thanavi for a fatwā, who ruled that due to apostasy the marriage was annulled (Masoud, 1996).

Before discussing this fatwā, it will be better to know about the three opinions of Hānāfī School of Islāmic jurisprudence about the apostasy of a woman.

The first opinion of Hānāfi jurist (Zahirul Rivaia) says that after the renunciation of Islam by the wife, the marriage bond is finished, but she will be forced to return to Islam and remarry her first husband, and until she does not accept Islam, she will be kept in prison (Rahman, 1965).

The second opinion of Hānāfi jurist from Samarqand and Bukhara that says that in the matter of renunciation of Islam by the wife, the marriage bond will remain valid, there will be no breach in the marriage bond and the renunciation of women will never make any effect on the marriage bond (Rahman, 1965).

The third opinion of another Hānāfi juristis says that the renounced women will be treated like a slave and her husband will remain her custodian.

It is evident that Ashraf Ali Thanavi gave his fatwā according to the first opinion of the Hānāfi School of Islāmic jurisprudence, according to which the marriage is dissolved after the renunciation of Islam by the wife. The first opinion also includes that a woman will be forced to remarry her first husband. But for courts, it was enough that Ashraf Ali Thanavi annulled the marriage. In addition forcing a woman to again accept Islam and to remarry her first husband was not possible in British India (Hussain, 2006). 
The court dissolved the marriage on the basis of this fatwā of Maulana Thanavi. The court verdict opened the doors for the Indian Muslim women to get separation from husbands. Before this decision, there was no remedy for the Muslim women of India to get rid of the marriage tie, because in case of demanding khulaa the consent of husband was necessary in Hānāfi school of Islamic jurisprudence. So, the rate of apostasy surprisingly increased after the fatwā of Maulana Thanavi. On the other hand, the Christian missionaries also contributed to it. They started to motivate the Muslim women to convert to Christianity and to get rid of their husbands. A missionary by the name of Reverend Paul in Lyallpur baptized several new converts and issued certificates of baptism. There were a number of Christian missionaries all over the India, who were working to convert Muslim women from Islam to Christianity (Masoud, 1996).

The religious political party of India, Jamiat-Ulema-e-Hind, were too much shocked by these conversions. They started demanding reforms in the Islämic law about dissolution (Hussain, 2006).

\section{Why Did Women Choose Apostasy for Separation}

The Islämic law has given the right of talaq (divorce) to men. The literal meaning of talaq is "to leave" or to "snap off" or "to separate". Divorce is right of the husband. He may use this right with reason or without reason. Islam has bounded men not to give divorce but legally no restriction is imposed on them. It has repeatedly said that divorce is only an evil. It is most detestable one among the lawful things, but whenever a husband wants to get rid of his wife, legally he can do.

Women have the right of khulaa and faskh to untie relation with their husbands. Khula is when wife has a dislike for her husband and ask him to be released her in exchange of some, or all parts of her Mehar. The real problem starts when wife wants separation and husband does not agree (Mansoori, 2006). Majority of Muslim scholars are of the opinion that the consent or approval of the husband is necessary in case of khulaa. It cannot be granted by the court on the request of wife if husband does not agree. It is also a fact that all the four Sunnī schools of Islämic jurisprudence do not allow khulaa without the consent of husband. So in the early part of twentieth century, the women started renouncing Islam because 
they were not having the right of khulaa, both Hānäfi jurists and courts were having the same opinion that the khulaa can only happen if husband agrees.

The word faskh means annulment or abrogation. In faksh, power lies with the Muslim judges to annul a marriage on the application of the wife. Majority of Muslims in the Subcontinent are follower of the Hānäfi School of thought, which in this regard is considered to be quite strict (Fayzee, 1999). Hānāfi jurists admit that only the wife of an impotent husband can apply for faskh (dissolution of marriage). In the matter of faskh, Maliki School of Islämic jurisprudence is considered to be more liberal for women. It requires ruling by the court in the following instance.

1. Illness or any defect in male.

2. Impotency of male

3. Cruelty or immoral treatment by husband

4. Missing of husband

5. Imprisonment of husband

6. Non-performing Maintenance

So from the above discussion it is clear that in Hāna $\bar{a} \hat{\imath}$ law, women do not have the right of khulaa without the consent of husbands. Similarly in case of faskh (dissolution of marriage) only the wife of an impotent husband could apply for faskh (dissolution of marriage). So if an Indian Muslim woman wanted to get rid of her cruel husband, she was not having any option. The Hānäfi School never recognizes the dissolution of marriage on the basis of non-maintenance, cruelty, imprisonment of the husband, missing husband, or on the basis of any defect in the husband. The most miserable condition was in the case of missing husband. According to the Hānāfi School of Islämic jurisprudence, the wife of the missing husband cannot get separation until the people of the same age of her husband are living alive. So, according to Ahnaf, the period is approximately eighty to one twenty years. Therefore in practical, she can never contract a second marriage. So these things forced the Muslim women of India to renounce Islam just to get rid of their cruel husbands. The Hāna fi law regarding dissolution of marriage was greatly blamed for these conversions.

\section{Revised Fatwa of Maulana Thanavi}

Maulana Thanavi realized the alarming situation and took the initiative to find a solution. He was greatly supported by Maulana Muhammad Shafi and Maulana Abdul Kareem Gumtoulve. He wrote a large number of letters to the scholars of 
Maliki School of Islāmic jurisprudence. Maulana Sayyed Hussain Ahmad Madni also helped Maulana Thanavi in this purpose. After several years of extensive consultation with muftīs (religious scholars) in India and abroad, Maulana Thanavi published a fatwā entitled "Al-Heela al-Najiza li'l-Hilat Al-'Ajiz". Eleven great Muftīs of Dar-al-Uloom Deoband helped Maulana Thanavi and also verified the fatwā. Similarly four Muftīs from Darul Aloom Saharanpur also verified the new fatwā. Maulana Zakria (the leading scholar of Tableeghy Jamat) is also included in this list (Thanvi, 1996).

In the new fatwā, Maulana Thanavi further ruled that apostasy does not annul a Muslim marriage; therefore a wife may obtain a judicial divorce based on Maliki School of Islāmic jurisprudence. He advised the wives that if they wanted to get rid of their husbands then first of all they should seek for khula from them. If the husbands do not agree, then the women can apply for dissolution of marriage on the basis of Maliki school of thought. Need was felt to amend the law through the legislation. The Jamiat-Ulema-e-Hind, one of the political parties of Ulema of India, strongly supported the revised fatwā of Maulana Thanavi.

Qazi Muhammad Ahmad Kazmi, a lawyer and member of the Indian Parliament from Meerut, presented a bill in the parliament for this reform. While presenting the bill in the Assembly, he said

The reason for proceeding with the bill is the great trouble in which I find women in India today. Their condition is really heartrending, and to stay any longer without the provisions of the bill and allow the males to continue to exercise their rights and to deprive women of their rights given to them by religion would not be justifiable- the rights of women should not be jeopardized simply because they are not represented in this house. I know, sir that the demand from educated Muslim women is becoming more and more insistent, that their rights be conceded to them according to Islämic law. I think a Muslim woman must be given full liberty, full right to exercise her choice in matrimonial matters (Legislative Assembly debate, 1939).

After long debates and several rounds of discussion, the bill was finally passed with the title of "Dissolution of Muslim Marriage Act, 1939". The section 4 of the Act provided that the apostasy of a Muslim wife did not annul the marriage contract. The Act allowed all grounds admitted in Maliki School of Islāmic jurisprudence for the dissolution of marriage. The Act also provided that the women can take decree from the court for dissolving marriage on the following grounds: 
- If the husband is missing

- If the husband is not providing maintenance

- If the husband is sentenced to imprisonment

- If the husband fails to perform marital obligation

- If the husband remains impotent for one year, or having other physical defects

- If the husband treats the wife with cruelty

The Dissolution of Muslim Marriage Act, 1939 provided the Muslim women a chance to get decree of dissolution from the court, without renunciation of Islam.

\section{Analysis of Dissolution of Muslim Marriage Act, 1939}

Section 2(i) of DMMA, 1939, states that a married Muslim woman shall be entitled to obtain a decree from the court if the whereabouts of her husband have not been known for a period of four years.

The period of four years is based on the doctrine of the Maliki School of Islāmic jurisprudence relating to the missing husband. When a wife asks the court for judicial separation for the reason that her husband is missing, the court will issue a notice of her suit to all the heirs of the husband, including his brothers and paternal uncles. Each of these persons will be heard by the court (Mahmood, 1982).

If the court passes the decree of fāskh (dissolution of marriage), it will not be effective for a period of six months and if during this period, the husband comes back and he satisfies the court about performing his conjugal duties, the court shall set aside the decree.

(i) If the husband is not found during the period of six months, then marriage will stand dissolved from the date of the decree.

(ii) If the husband is traced but does not come back at the expiry of said six months, the decree will take effect. Unless, it is submitted, the wife applies to the court for its cancellation.

(iii) If the husband returns but fails to satisfy the court of his willingness to perform conjugal duties, effect may still be given to the decree on the application of the wife. 
According the Hānāfi School of thought, the wife of the missing husband cannot get separation until the people of the same age of her husband are alive (Hamilton, 1963). So, according to Ahnaf, the period is approximately eighty to one twenty years. But in some situation, the judge can issue the decree of dissolution without any delay. For example, if somebody goes to battle and does not come back. Similarly, if somebody goes on a sea voyage and never returns to the beach. Other than these conditions, the Hānāfi law does not give any ground for separation till the period of same age group persons are alive.

According to Imam Mālik, in case of Māfqood al Khabar or a missing person, the wife has to wait for four years, after which she may approach the court to get the decree of dissolution of marriage and can go for second marriage.

Ashraf Ali Thanavi in his fātawā "Al-Helal-Najiza lil-Helatil Ajiza" highlighted the Māliki point of view about the missing person. He says,

"It is a unanimous decision that the wife of a missing husband can only be restricted for four years if she can lead or observe that time with chastity and can observe the limits of God(Hudood ofAllah)" (Thanvi, 1996).

According to Māliki School of Islāmic jurisprudence, the period of four years can be reduced to one year if there is fear that she may involve in illicit relations or cannot observe the limits of God (Thanvi, 1996). In most of the fātwā, the Hānāfi jurists mentioned that if a husband is missing and the woman does not have maintenance then only limit of four year could be reduced. The top Hānāfi muftis held the same opinion, in their fātwā by saying that this limit could be reduce to one year. For example in Fatwā Usmani, Maulana Taqi Usmani also gave the following verdict:

"Period of four years can be reduced to one year if there is a fear that the woman cannot lead that period with chastity or cannot observe the limits of God" (Fatawa Usmani).

In Fatwā Usmanyit is clearly mentioned that

"If the husband is missing for minimum one year, and it is feared that the woman cannot observe that period with chastity then without any delay the $q \bar{a} d \bar{l}$ could dissolve such marriage" (Fatawa Usmani). 
Similarly in Ahsan ul Fatwā, Muftī Rasheed Ahmad has the same opinion about the missing husband (Ahsan Al Fatawa).

It is clear that the Hānāfī Muftīs based their fatwās on the true doctrine of Maliki School of Islāmic jurisprudence. So the DMMA, 1939 could be further amended according to these ruling.

Section 2(ii) of DMMA, 1939, states that a married Muslim woman shall be entitled to obtain a decree from the court if the husband ignores or fails to provide her maintenance for a period of two years.

The maintenance in the language of Islāmic law means 'provision of all those things which are necessary to support life, like food, clothing and lodging'. When a woman surrenders herself to her husband then she has right of receiving maintenance from her husband. Now it is obligation of her husband to provide her maintenance.

According to the Hānāfi jurists, there cannot be separation on the basis of nonmaintenance. The wife will bear expenditure from her own resources or will borrow on behalf of her husband, unless her husband is able to give her maintenance. According to Ahnaf, non-maintenance can never become a reason for the dissolution of marriage (Rahman, 1965). They say that there is not a single incident in the period of Holy Prophet Muhammad (P.B.U.H) about the dissolution of marriage based on non-maintenance. Some companions of the Prophet were rich and some were very poor. We do not have a single example, where there is separation among the spouses on the basis of non-maintenance.

According to Ahnaf, if a husband is rich and does not provide maintenance to his wife then instead of dissolving the marriage the judge can send the husband to prison or sell his assets to provide the maintenance to the wife. If the husband is poor, then also there cannot be separation among the spouses. The wife should wait for good days.

Maliki jurists agree that if the husband is poor and does not provide maintenance to his wife and if she cannot live in such a situation, then she has the right to ask the judge or qādī for maintenance or can request the court to allow separation from her spouse (Rahman, 1965). 
So if the husband is not providing maintenance to his wife then it means he is not keeping her in a recognized manner. In such situation, the woman has the right to ask the court for the dissolution of her marriage as there is no other solution. The judge has the entire jurisdiction to untie such marriage.

But if we study the Maliki School of Islāmic jurisprudence, we find that the twoyear period is not a hard and fast rule. According to Maliki School of Islāmic jurisprudence, if a husband is rich and in spite of this he does not provide maintenance to his wife, the court can grant a decree in the favor of the woman without any delay. Similarly if a husband is poor and does not have maintenance and the court concludes that he has no financial resources, such marriage can also be ended without any delay. So from this point, we can conclude that it should be added to the law that if a husband is not poor and has sufficient financial resources the court should not allow delay in the dissolution of marriage (Thanvi, 1996).

Ashraf Ali Thanavi, in his book "Al-Helal-Najiza lil-Helatil Ajiza", clearly mentioned the point of view of Maliki School of Islāmic jurisprudence that if a husband does not provide maintenance to his wife then the court can dissolve the marriage without any delay (Thanvi, 1996).

By explaining Maliki point of view about non-maintenance, Muftī Muhammad Taqi Usmani clearly mentioned that in case non-maintenance, there is no need of waiting period, Fatawa Usmani. He said that only two conditions are necessary in the matter of non-maintenance. The first condition is that if a husband does not agree for khula and secondly, a woman has not any alternate arrangement of maintenance (Fatawa Usmani).

So, the Article 2(ii) does not represent the complete intention of the Maliki School of Islāmic jurisprudence. Further according to the rule of tâlfeeq, when we are taking the opinion of other school of Islāmic jurisprudence then all portions of that rule should be included (Thanvi, 1996). It should be added in clause 2(ii) that if a husband is not poor and not providing the maintenance the court may dissolve the marriage without any delay and the restriction of two years is not necessary. Similarly if a husband is so poor that he will never be able to provide the maintenance in future, the court should also dissolve such marriage without any delay. 
In Some decision of Indo-Pak courts, it is found that their decisions were not representing the motives of DMMA, 1939. For example the Sindh High court gave the ruling that:

(i) "The husband's failure or neglect must have lasted for full two years immediately preceding the wife's suit. Failure for broken periods aggregating to two years will not satisfy the legal requirement",

(ii) "The husband's failure for two years or more followed by a period during which maintenance was resumed, will also not satisfy the legal requirement", Satgunj vs Rehmat Ali (AIR, 1946).

So, it means that if a husband does not provide maintenance for one year to his wife, then gives maintenance for one or two months and again stops the maintenance, then the wife will not be entitled to dissolution of marriage on the basis of non- maintenance. The court should also keep in mind the intention of the husband; he may do this just to tease his wife. The objectives of marriage can also be violated with such a decision.

Some of the courts did not grant $f \bar{a} s k h$ by saying that

"A wife not living with her husband, she can not claim fāskh on the basis of nonmaintainanc", Mst Umat-ul-Hafiz vs Talib Hussain (AIR 1944, Lahore).

In another decision it was held

"That on living separate from their husbands then the court cannot grant fāskh on the basis of non-maintenance because she has failed to perform her conjugal duties", Umatul Hafiz vs Talib Hussain(AIR 1945, Lahore).

In 1943, the court also decided that

"If a wife was unfaithful then the court could not grant decree on the basis of non-maintenance", Khatijian vs Abdullah (AIR 1943, Sindh).

This court decision was based on the Muslim legal principle under which disobedience of the wife (nushuz) disentitles her to claim maintenance.

DMMA, 1939 does not mention that women could only get the separation if she is living with her husband for complete two years, but colonial courts gave more weightage of wife living with her husband for complete two years. Instead of 
calculating two full years of non-maintenance, the courts should see the intention of the husband. For example in case a husband does not give any maintenance to his wife or does not treat her in a good manner, she leaves her matrimonial home just for survival and start living in her parents home. After some months, when she approaches the court for the dissolution of marriage on the basis of nonmaintenance, the husband may take the plea that since she is not living with him so how could he maintain her. So the courts should always consider the intention of the husband instead of considering the absence of the wife from her matrimonial home. Almost all the great religious scholars of the Subcontinent while issuing the fatwa clearly mentioned that without any delaying period the court could dissolve the marriage in the case of non-maintenance (Thanvi, 1996).

Section 2(iii) of DMMA, 1939, states that a married Muslim woman shall be entitled to obtain a decree from the court if the husband has been sentenced to imprisonment for a period of seven years or more.

The Hānāfi jurists do not recognize the dissolution of marriage on the basis of husband's imprisonment (Nasir, 1986).

In the view of Maliki School of Islāmic jurisprudence, the wife can ask for the dissolution of marriage if her husband has been imprisoned for three years and for some Maliki jurists if the husband is imprisoned for one year.

The decree shall only be passed if the sentence has become final. If in the meantime the husband does not provide the maintenance to his wife for a period of two years, she will be entitled to take advantage of clause 2(ii) (Shafqat, 1955).

As we have seen that in the Maliki School of Islāmic jurisprudence only a period of three years is a maximum period or one year, if her husband has been sentenced to imprisonment. But in the Dissolution of Muslim Marriage Act, 1939, a woman is bound to wait for minimum seven years for separation. This shows that the 2(iii) is also against the Maliki School of Islāmic jurisprudence. In the case of missing husband, the Maliki School of Islāmic jurisprudence has a clear stance that if a woman cannot wait and a threat to the limits of God is there then the period of four years can be reduced to one year. 
Section 2(iv) of DMMA, 1939, states that a married Muslim woman shall be entitled to obtain a decree from the court if the husband has failed to perform, without any reasonable cause, his marital obligation for a period of three years;

The Act does not specify "marital obligation" of the husband. It seems that a wife can file a suit for fāsk hunder this provision, if her husband has deserted her for three years, though he has been providing maintenance to her (Mahmood, 1982: p. 101). If desertion for three years is coupled with non-payment of maintenance, a suit may be filed jointly under clauses (ii) and (iv) of section 2. An obligation to live in amity would be a marital obligation, thereby excluding cruelty. Refusal to consummate also falls within the phrase, and that will include an insistence by one spouse, without the consent of the other (Shafqat, 1955).

Maulana Thanavi, by citing the Maliki law, clearly mentioned that even if a woman can arrange her maintenance by herself but if there is a threat that she will not be able to observe the chastity or it is threat that the limits of God can be violated then she can approach the court for the dissolution of marriage (Thanvi, 1996). The court will force the husband to perform his duties and if he does not act upon it, it can grant fāskh without any delay and there is no need to ask her to wait for three years,

We also examine that in case of ilaa the limit of four months is fixed. If the husband does not rejoin his marital relations with his wife, she will be allowed to go for fāskh (dissolution of marriage). If this is the case, then the question arises that why women are restricted for three years in the DMMA, 1939?

Mowdoudi, an Islamic political leader, debated this topic that if a husband without any reasonable cause abstains from his wife and his purpose is just to punish or tease his wife then the maximum period, which Islam fixes, is four months. For ilaa, the oath or swear of a husband is necessary. Without oath or swear the ilaa would not be establish. Let's suppose that just to tease the wife, the husband abstains from her for whole life and he does it without swearing. What should be the solution then? For this we will have to see the objectives of marriage which include chastity. We will have to see how long this purpose of marriage can be achieved (Mowdoudi, 1965).

Section 2(vi) of DMMA, 1939 states that married Muslim women will be entitled to obtain a decree from the court if the husband has been insane for a period of two years or is suffering from leprosy or a virulent venereal disease. 
According to Ahnaf, only the wife of an impotent man can have the decree of dissolution from the court (Nasir, 1986). Imam Muhammad, another great Hānāfi jurist, also included an insane husband and a husband suffering from a venereal disease. According to Imam Muhammad, these problems can create hatred between the spouses, which can ultimately be a hurdle in their physical relations. According to Imam Abu Hānāfi, insanity or venereal disease does not lead to the dissolution of marriage.

The Malikijurists hold the opinion that a woman can have the decree from the court for the dissolution of marriage on the basis of leprosy, insanity, impotency, and venereal disease. Imam Malik included four problems in a husband, which grants her the right of dissolution of marriage. This list includes impotency, leprosy and virulent venereal disease.

The DMMA, 1939 does not define insanity. The insanity is also known as junoon in Arabic. There are two kinds of insanity. One is called incurable insanity (junoon Mutabbaq) and the second is curable insanity (junoon Hadis). Junoon Mutabbaq is such kind of insanity or junoon in which insanity is not curable, means the person suffering from it remains in this condition permanently and no chance of improvement is there. On the other hand junoon Hadis is such kind of junoon which is curable. For the two categories of junoon, there are different rules in Maliki law. If a husband is suffering with such kind of junoon which is Mutabbaq and he might harm the wife during this situation then there is no need to give any time for the dissolution of marriage, the court can dissolve the marriage without delay. But if there is junoonHadis then the court should allow one year period for treatment. But in DMMA, 1939 the condition of two years is kept, which is against the Maliki School of Islāmic jurisprudence as well as against the spirit of the Shari'ah. Because in Maliki law there are only two conditions, if there is junoon Hadis then on year time is fixed for treatment and for junoon Mutabak there is no need of waiting period, so clearly DMMA, 1939 is deviated from the Maliki school of thought.

Section 2(ix) of DMMA, 1939, states that a decree passed on ground mentioned earlier shall not take effect before a period of six months, from the date of court verdict, and if the husband either in person or through his authorized agent satisfies the court within this period that he is prepared to perform his conjugal duties, the court shall set aside the decree. 
Literally, the word iddah means counting or enumeration. Iddah technically means a waiting period which has to be observed by the woman after the dissolution of marriage. After dissolution of marriage she must have to observe this period. According to Imam Abu Hanifa, a menstruating woman, whose marriage has been dissolved, after the consummation must have to observe iddah, which is three menstruation periods? According to Imam Shafie and Imam Malik, the waiting period for such woman is three cleaning periods. In the case of non-menstruation, the waiting period or iddah is three months. In the case of a widow, the waiting period of iddah is prescribed as four months and ten days. Similarly, the iddah for a pregnant woman will be terminated with the delivery of the baby.

Muftī Muhammad Taqi Usmani in all fatwās regarding the dissolution of marriage, in his book Fatwā Usmani, clearly mentioned that after the decree of dissolution or after divorce, the woman needs to perfrom iddahwhich is stated in Islāmic law. So, it is needed to make this section of DMMA, 1939 more according to Islāmic law.

\section{Conclusions}

We come to the conclusion that it was a great effort by the Hānāfîscholars of $20^{\text {th }}$ century. The basic relief assured to the Muslim women of India was that they could untie the marital relation without renunciation of Islam. However, on a close examination we find a number of lapses in the DMMA, 1939, which are against the Maliki School of Islāmic jurisprudence. If we amend the DMMA, 1939 according to the doctrine and intention of Maliki School of thought, it will provide more reliefs to the women. We should also congratulate the Hānāfisscholrs, who gave the fatwā keeping in view the true doctrine of Maliki School of Islāmic jurisprudence after the adaptation of Dissolution of Marriage Act, 1939.

\section{References}

Ahsan al fatwā, Baab Khiyar al fäskh 
Fyzee, A. A. A. (1999). Outlines of Muhammadan law. Delhi: Oxford University Press.

Hamilton C, (1963). Hedaya: English Translation Premier Book House, Lahore, p. 213.

Hussain, S. (2006). Muslim Women's Rights Discourse in the Pre-Independence Period, available online at: www.cwds.ac.in/OCPaper/ sabihaOccasionalPaper.pdf

Legislative Assembly debate 1939:616

Mahmood, T. (1982). The Muslim Law of India. Allahbad: The Law Book Company.

Mansoori, T. (2006). Muslim Family Law in Islam. Islamabad: Sharī'ah Academy

Masoud, M.K. (1996). Apostasy and Judicial Separation in British India, Harvard University. $\quad$ Retrieved from globalwebpost.com/farooqm/study_res/islam/fiqh/masud_apostasy.doc

Mowdoudi, Abu.al. (1965). Haqooq al Zojain. Lahore: Idara Tarajuman al Qur'an.

Mst Umat-ul-Hafiz vs Talib Hussain, AIR 1945 Lahore, 56; Zafar vs Akbari, AIR 1944 lahore. 336,337

Nasir, J.J. (1986). The Islāmic Law Of Personal Status. London: Graham and Trotman.

Rahman , Al.T. (1965). Majmoo'a $i$ Qawaneen $i$ islam. Islamabad: IslamicResearch Institute.

Satgunj vs Rahmat Dil, AIR (1946). Sindh48. The maintenance contemplated is provision of food, rainent and lodging adequate for the wife taking into consideration the husband's station in life. Half-hearted illusory attempts to provide maintenance contemplated by Dissolution of Muslim Marriage Act, 1939. 
Shafqat,M.C. (1955). The Muslim Marriage,Dower and Divorce. Lahore: The Law Book Company

Thanavi, Ali. A. (1996). Al-Heela al-Najiza li'l-Hilat Al-'Ajiza. Lahore: Al faisal publisher.

The all Pakistan Legal Decisions, vol. 23 (1). (1971). Khatijian vs Abdullah, AIR 1943 Sind, 65

Usmani, M.T. (2004). Fatwā Usmani, Maktiba Maraful Quran Karachi, volume 1, pp. 216-218.

Yasir Arafat is Teaching \& Research Associate in the Department of Media Communication Studies, International Islamic University, Islamabad. 